\title{
在宅高齢者の健康と食事内容の実態調査
}

\author{
真鍋 久*・岡本 睦友 $* *$ ・鈴木 秀子***
}

〔*鳥取大学農学部（現在 会津大学短期大学部），**内池醸造株式会社，***会津大学短期大学部〕

\section{Investigation of the health status and meal contents of community-dwelling elderly people}

\author{
Hisashi Manabe*, Mutsutomo Okamoto**, Hideko Suzuki***
}

*Faculty of Agriculture, Tottori University, Koyama Tottori, 680-8553 (Present: Aizu Junior College of Fukushima Prefecture, Ikkimachi Aizuwakamatsu, 965-8570)

**Uchiike Distillation Company, Nishikamishinden Senoue Fukushima, 960-0101

***Aizu Junior College of Fukushima Prefecture, Ikkimachi Aizuwakamatsu, 965-8570

\author{
*テ680-8553 鳥取市湖山町南 4-101 \\ **干960-0101 福島市瀬上町字西上新田 1-7 \\ ***⿳965-8570 福島県会津若松市一箕町大字八幡字門田 1-1
}

Health status and meal contents of community-dwelling elderly people were investigated. The following results were obtained.

(1) While health status decreased with an increase in age among elderly people in their 80 s, it increased among elderly people older than 90 years.

(2) More than $20 \%$ of the elderly people had lost all of their teeth. The average number of remaining teeth was 11 (33.8\% survival rate), and decreased with an increase in age. The average loading rate for artificial teeth exceeded $80 \%$. The loading rate rose when the number of remaining teeth was 19 or less, and the rate was significantly lower when the number of remaining teeth exceeded 19 (59.4\% survival rate). Many elderly people were not satisfied with the loading condition of artificial teeth. More elderly people had problems with their bite condition (19.6\% of the total) than with their swallowing condition (7.8\% of the total). The degree of an individual's swallowing condition was strongly correlated with his or her health status.

(3) For many elderly people, boiled rice is the staple food, and is most frequently eaten at breakfast. Nutritional supplementation was found to be more easily prepared at breakfast than at any other meal. Nutritional supplementation was found to be unbalanced at lunch because elderly people frequently eat only one kind of dish. Fruits were consumed most frequently as a desert. Concerning the intake-frequency of various foods, the intake of only pickled vegetables (tsukemono) decreased with an increase in age, deterioration of health status, and with reduced bite or swallowing conditions. Although very few elderly people utilize processed foods developed for the dietary needs of the elderly, which are recognized as convenient by some elderly people.

Based on the analytical results shown above, countermeasures for allowing the elderly to more comfortably eat meals are discussed.

\section{I . はじめに}

わが国の65歳以上の人口は，平成 17 年 10 月 1 日の時点
で過去最高の 2,560 万人に達しており，これは総人口の $20 \%$ 余りにあたる ${ }^{1)}$ 。高齢者人口は年々上昇しつつあり, 国立社会保障・人口問題研究所の推計によると 10 年後の 
平成 26 年には 65 歳以上の人口が $25 \%$ を越す見込みであ $3^{2)}$ 。

また，高齢者のいる世帯は平成 16 年現在 1,786 万世帯 （全世帯の37.7\%）であり，その内訳は，高齢者単独世 帯373万 $(20.9 \%) ，$ 高齢者夫婦の久の世帯525万（29.4 $\%)$ ，親と子のみの世帯293万 $(16.4 \%)$, 三世代世帯392 万 $(21.9 \%)$ である。したがって，高齢者単独世帯と高 齢者夫婦のみの世帯を合わせた「高齢者たけの世帯」が 全世帯の $50 \%$ にも達していることになる11。

ところで，我が国の高齢者の栄養状態は決して望まし いものではない。たとえば平成 7 年からの 4 年間にわた る継続調査によると，血清アルブミン值 $3.5 \mathrm{~g} / \mathrm{d} 1$ 以下と いう「タンパク質・エネルギー低栄養状態」の者は，地 域に在住する自立高齢者では $10 \%$ に満たないものの, 在 宅訪問患者では約 $30 \%$ を，また病院外来高齢患者でも 10 \%程度を占めるなど，「日常生活動作」が低下した高齢 者で多くなっているという3)。

高齢社会対策基本法4)に嵒われている“長寿をすべて の国民が喜びの中で迎え，高齢者が安心して暮らすこと のできるような社会”では，高齢者のだれもが不安を持 たずに食生活を営むことのできる状態が実現していなけ ればならない。

以上の背景のもと，高齢者の食生活の実態がどのよう なものなのかを把握するための調査を行った。今回は, (1)高齢者の健康状態，(2)食事行為と深い関わりを有する 歯 (咀嚼) と喉（嚥下）の具合，(3)日摂取している食 事内容の 3 点に絞って解析を行ったので，その結果を報 告する。

なお，ごく一般的な高齢者の実態を把握したいとのこ とで，対象者は，著者らの活動地域である福島県内に在 住する「独居していない在宅高齢者」（次項II参照）と した。

\section{III. 調査の概要}

アンケート調査（留め置き法）を実施した。調査内容 の記載者は，実際に食事づくりを担当している者とした。 したがって，対象者が食事づくりをしている場合は自己
記入がなされ，そうでない場合は，食事づくりを担当し ている者が聞き取りと記入を行った。

対象者は, 県内の 9 市 1 町に在住する65歳以上の在宅 者とした。ただし，独居はして抢らす，寝たきり状態で はないなど大きな支援を必要としない者に限定した。対 象者の在住地と人数は福島市 88 人, 会津若松市 103 人, いわき市 111 人，喜多方市 103 人，郡山市 67 人，白河市 72 人, 相馬市 50 人, 田島町 (現南会津町) 86 人, 原町市 (現南相馬市） 81 人の合わせて 759 人である。

調査は主として平成13年の晚秋に行い，その後も数年 かけて補足調査をした。

以下に調査内容を示す。先ずは対象者の全般的な健康 状態である。「体調」については「良い・普通・時々悪 くなる・療養中」から一つを選択してもらった。「時々 悪くなる」または「療養中」が選択された場合は, 続け て, 病名や病気の内容等を差し支えない範囲で記載して もらった。

二つ目は歯（咀嚼）と喉（與下）の状態についてであ る。食べ物の「噛久具合」を「良い・普通・あまり良く ない・良くない」から一つ選択してもらった。「あまり 良くない」または「良くない」が選択された場合は，不 具合の状態についても記載してもらった。さらに，入れ 歯の有無ならびに自歯（残存歯）の本数を尋ねた。

「飲み込反具合」についても，「良い・普通・あまり良 くない・良くない」から一つを選択してもらった。「あ まり良くない」または「良くない」が選択された場合は， 不具合の状態を記載願った。

三つ目は食事内容の調査である。表 1 に掲げた「記入 例」を参考に，ある一日に摂取した全ての食事の中身と 大まかな摂取量を記入してもらった。ただし調査日は八 レの日などの特別日を除いたごく平凡な日とした。

\section{III.調査結果ならびに考察}

\section{(1) 対象者の概要}

対象者を年齢の高さに応じて 4 段階に区分し，各年代 ごと男女別に人数を集計したものが表 2 である。年代の 上昇に伴い女性の占める割合が顕著に高くなっていた。

記入例 (平成@年 $\bigcirc$ 月 $\Delta$ 日の食事内容)

\section{表 1 食事内容の記入例}

\begin{tabular}{|c|c|c|c|}
\hline 種 類 & 朝 食 & 昼 食 & 夕 食 \\
\hline 主食 & 米飯茶碗軽<一膳 & $\begin{array}{l}\text { 天ぷらソバ一人前（かき揚げ, } \\
\text { エビ, イカ） }\end{array}$ & おちにぎり一個（梅干し・海苔） \\
\hline おかず & $\begin{array}{l}\text { 沢庵 三切れ 納豆（ウズラ卵い } \\
\text { り）少々 焼きサバ一切れ }\end{array}$ & ほうれん草おひたし少々 & $\begin{array}{l}\text { 秋刀魚一尾 大根おろし少々 おでん } \\
(\text { 卵·根・はんぺん) }\end{array}$ \\
\hline 汁物 & $\begin{array}{l}\text { みそ汁一杯 (具はわかめ, ネギ, } \\
\text { ジャガイモ, 豆腐) }\end{array}$ & 主食（天ぷらソバ）と同じ & $\begin{array}{l}\text { 豚汁一杯 (大根·人参・ゴボウ・里芋 } . \\
\text { 生姜・豚肉・ネギ） }\end{array}$ \\
\hline デザートなど & 食後にプリンヨーグルト一個 & リンゴ 1 / 4 個 & 日本酒一合 \\
\hline その他 & \multicolumn{3}{|c|}{ 朝食の前に牛乳を一本のむ。 おやつとしてあんパン一個。 } \\
\hline
\end{tabular}

$118(24)$ 
表 2 調査対象者の人数（年代別·男女別）

\begin{tabular}{c|c|c|c|c|c}
\hline & \multicolumn{7}{|c|}{ 年 齢 構 成 } & & \\
\hline 性別 & $65 \sim 69$ 歳 & 70 歳代 & 80 歳代 & 90 歳以上 & 合 計 \\
\hline 男 性 & $82(48.0)$ & $135(37.0)$ & $48(28.4)$ & $7(15.2)$ & $272(36.2)$ \\
女 性 & $89(52.0)$ & $230(63.0)$ & $121(71.6)$ & $39(84.8)$ & $479(63.8)$ \\
\hdashline 小 計 & $171(100)$ & $365(100)$ & $169(100)$ & $46(100)$ & $751(100)$ \\
\hdashline 男女不明 & 2 & 2 & 3 & 1 & 8 \\
\hline 合 計 & 173 & 367 & 172 & 47 & 759 \\
\hline
\end{tabular}

表 3 健康状態（年代別人数）

（）内は\%

\begin{tabular}{|c|c|c|c|c|c|}
\hline \multirow[b]{2}{*}{ 年歯構成 } & \multicolumn{4}{|c|}{ 健康状態 } & \multirow[b]{2}{*}{ 合 計 } \\
\hline & 良い & 普通 & 時々悪くなる & 療養中 & \\
\hline $65 \sim 69$ 歳 & $50(29.9)$ & $92(55.1)$ & $8(4.8)$ & $17(10.2)$ & $167(100)$ \\
\hline 70歳代 & $86(24.9)$ & $181(52.3)$ & $33(9.5)$ & $46(13.3)$ & $346(100)$ \\
\hline 80歳代 & $45(26.9)$ & $80(47.9)$ & $17(10.2)$ & $25(15.0)$ & $167(100)$ \\
\hline 90 歳以上 & $14(32.6)$ & $23(53.5)$ & $4(9.3)$ & $2(4.7)$ & $43(100)$ \\
\hline 合 計 & $195(27.0)$ & $376(52.0)$ & $62(8.6)$ & $90(12.4)$ & $723(100)$ \\
\hline
\end{tabular}

\section{（2）健康状態}

対象者の健康状態を表 3 に示した。回 答者の79.0\%が「良い」(27.0\%) もし くは「普通」(52.0\%) として抢り，「時 々悪くなる」 $(8.6 \%)$ と「療養中」 (12.4\%) を大きく上回っていた。よっ て, 在宅高齢者の多くは健康であるとい える。ただし, 在宅高齢者であっても 「寝たきり」や「独り身」の者は除いて いるので，自宅でごく普通に過ごしてい る高齢者だけを調査した結果であること に留意しなければならない。

健康状態を年代別に比べてみると，80 歳代までは「時々悪くなる」と「療養中」 が順次高くなっていた。しかしながら90 歳以上ではどちらも低下しており, とく に「療養中」の低下が顕著であった（表 3 )。したがって，年齢がとくに高い在 宅高齢者は, 概して健康上の問題が少な いと見てとれる。

\section{(3) 歯と喉の具合}

\section{1) 自歯の残存状態}

対象者を選ぶ際には男女の別を意識してはいない。また 対象者の家族構成は，(1)夫婦高齢者，(2)夫婦高齢者＋家 族，(3)単身高齢者＋家族の 3 パターンになるが，(1)や(2) の場合はできるだけ夫婦を対象者とするようにした。ゆ えに，年齢の高まりに伴って入院したり，寝たきりにな ったり，亡くなったりする高齢者は，女性よりも男性で 多くなっているものと思われた。平均寿命や健康寿命は 男性よりも女性で高いという一般的な状況と矛盾しない 結果である。

対象者の人数を前期高齢者（65～74歳）と後期高齢者 （75歳以上）で比較したところ，前者は373人（49.1\%)， 後者は 386 人 $(50.9 \%)$ であった。ところで県内の高齢 者全体に占める後期高齢者の割合は $43.1 \%$ (平成 13 年 8 月）5であり，先の場合よりもかなり低い。したがって， 今回の調査には多くの後期高齢者に参加してもらえてい るといえよう。
対象者が，「自歯無し」(残存歯 0 本）から「全てが自 歯」(残存歯32本) までのいずれに該当するのかををと めたものが表 4 である。残存歯の無い者が 121 人（回答 該当する者は, 残存歯の多少にかかわらず，いずれも僅 か 15 人前後であった。さらに, 残存歯が 24 本程度を越え た場合は, 残存歯数が多くなるにつれて該当者数が減少 気味にあった。

全て自歯という残存歯 32 本の者は 4 人で，その内訳は 70 歳代の男性 2 人, 60 歳代の女性 2 人であった。健康状 態はいずれも「良い」または「普通」であった。

残存歯数を年代別に比較したところ，60歳代16.2本 (残存率 $50.6 \%), 70$ 歳代 11.1 本 $(34.7 \%), 80$ 歳代 5.5 本 $(17.2 \%), 90$ 歳以上 4.0 本 $(12.5 \%)$ であり, 年代の上 昇に伴い減少していた。なお，残存歯数の平均は10.8本 （残存率33.8\%）であった。わが国では8020運動が展開 者の $23.2 \%$ ）にも及んでいた。次に, 残存歯 $1 \sim 4$ 本に

表 4 残存歯数 0 本〜32本に該当する者の分布状態

\begin{tabular}{c|cccccccccccccccccccc}
\hline 残存歯数 & 0 & 1 & 2 & 3 & 4 & 5 & 6 & 7 & 8 & 9 & 10 & 11 & 12 & 13 & 14 & 15 & 16 & 17 & 18 & 19 \\
\hline 人 数 & 121 & 12 & 16 & 13 & 17 & 29 & 21 & 9 & 18 & 8 & 36 & 5 & 12 & 6 & 7 & 18 & 18 & 5 & 16 & 5 \\
\hdashline$\%$ & 23.2 & 2.3 & 3.1 & 2.5 & 3.3 & 5.6 & 4.0 & 1.7 & 3.5 & 1.5 & 6.9 & 1.0 & 2.3 & 1.2 & 1.3 & 3.5 & 3.5 & 1.0 & 3.1 & 1.0 \\
\hline$\%$
\end{tabular}

\begin{tabular}{c|ccccccccccccc|c}
\hline 残存歯数 & 20 & 21 & 22 & 23 & 24 & 25 & 26 & 27 & 28 & 29 & 30 & 31 & 32 & 合 計 \\
\hline 人 数 & 29 & 7 & 12 & 6 & 16 & 9 & 8 & 11 & 16 & 7 & 4 & 2 & 4 & 520 \\
\hdashline$\%$ & 5.6 & 1.3 & 2.3 & 1.2 & 3.1 & 1.7 & 1.5 & 2.1 & 3.1 & 1.3 & 0.8 & 0.4 & 0.8 & 100 \\
\hline$\%$
\end{tabular}


中であり，80歳で自歯20本を保有する ことが歯科保健の目標とされている6)。 今回の調査結果では, 80歳代で目標本 数の30\%足らず，70歳代でも $60 \%$ 足ら ずであり，60歳代ですら数本足りない など目標を大きく下回っていた。

\section{2 ) 入れ歯の状態}

入れ歯装填の有無については, 回答 者 719 人のうちの 581 人 $(80.8 \%)$ が 「有」としていた。

装填は，自歯無しの者から残存歯30 本の者にまで渡っており，自歯無しの 者の装填率は95.9\%であった（表5)。 な掞，入れ歯装填者の総数と入れ歯装 填率が前段に示した值と多少異なって いるが，これは「入れ歯の有無」の記 載があっても「自歯数」の記載されて いない調査票を除去したことによる。

入れ歯の装填率は，残存歯18本程度 までは残存歯数にかかわらず高い状態 で維持されており，19本（残存率59.4\%）程度を越える と装填率が明確に減少していた（表5）。したがって，全 歯数 32 本の $60 \%$ 程度を境に，自歯がこれよりも少なくな ると食物の噛み具合に支障を来たす度合いが高くなり， 入れ歯を装填せざるを得なくなってしまうことが示唆さ れた。食物を咀嚼する際に歯がなくても「がまん」ので きる限界が，残存歯19本あたりにあるのかも知れない。 8020 運動における自歯の目標数が20本であること淂とほ ぼ符合しており興味深い。

\section{3 ) 噛み具合}

噛み具合の状態を表 6 に示した。「良い」(20.0\%) と
表 6 噛み具合の状態（年代別人数）

\begin{tabular}{|c|c|c|c|c|c|}
\hline \multirow[b]{2}{*}{ 年歯椯成 } & \multicolumn{4}{|c|}{ 噛及具合 } & \multirow[b]{2}{*}{ 合計 } \\
\hline & 良い & 普通 & あまり良くない & 良くない & \\
\hline $65 \sim 69$ 歳 & $38(23.0)$ & $100(60.6)$ & $20(12.1)$ & $7(4.2)$ & $165(100)$ \\
\hline 70歳代 & $58(17.3)$ & $218(64.9)$ & $43(12.8)$ & $17(5.1)$ & $336(100)$ \\
\hline 80歳代 & $34(21.1)$ & $84(52.2)$ & $29(18.0)$ & $14(8.7)$ & $161(100)$ \\
\hline 90歳以上 & $10(26.3)$ & $21(55.3)$ & $4(10.5)$ & $3(7.9)$ & $38(100)$ \\
\hline 合計 & $140(20.0)$ & $423(60.4)$ & $96(13.7)$ & $41(5.9)$ & $700(100)$ \\
\hline
\end{tabular}

表 7 噛み具合と健康状態の関係

\begin{tabular}{|c|c|c|c|c|c|}
\hline \multirow[b]{2}{*}{ 健康状態 } & \multicolumn{4}{|c|}{ 噛久具合 } & \multirow[b]{2}{*}{ 合計 } \\
\hline & 良い & 普通 & あまり良くない & 良くない & \\
\hline 良い & $74(41.0)$ & $91(50.8)$ & $11(6.1)$ & $3(1.7)$ & $179(100)$ \\
\hline 普通 & $41(11.8)$ & $244(70.1)$ & $42(12.1)$ & $21(6.0)$ & $348(100)$ \\
\hline 時々悪くなる & $7(11.9)$ & $30(50.8)$ & $17(28.8)$ & $5(8.4)$ & $59(100)$ \\
\hline 療養中 & $13(15.5)$ & $40(47.6)$ & $22(26.2)$ & $9(10.7)$ & $84(100)$ \\
\hline
\end{tabular}

回答した者は 670 人，（）内は\%

「普通」(60.4\%) の合計が $80 \%$ を越えており，「あまり 良くない」(13.7\%) や「良くない」(5.9\%) を大きく 上回っていた。なお，年代が高くなるにつれて「あまり 良くない」「良くない」ともに増加状態にあった。 たたし「90歳以上」では「あまり良くない」「良くな い」のいずれもが70歳代程度にまで減少しており，噛み 具合の「不具合」が確実に減少していることがわかった。

噛久具合の程度を健康状態との関係でまとめたものが 表 7 である。噛久具合が「あまり良くない」と「良くな い」は，健康状態の良い者でそれぞれ $6.1 \%, 1.7 \%$ と低 く，時々悪くなる者で $28.8 \%, 8.4 \%$ と高くなり，普通

表 5 入れ歯の装填状態*

\begin{tabular}{|c|c|c|c|c|c|c|c|c|c|c|c|c|}
\hline 残存歯数 & 0 & 1 & 2 & 3 & 4 & 5 & 6 & 7 & 8 & 9 & 10 & \\
\hline \multirow[t]{2}{*}{ 入れ歯 } & 116 & 12 & 16 & 11 & 13 & 27 & 17 & 9 & 15 & 8 & 31 & \\
\hline & 5 & 0 & 0 & 2 & 4 & 1 & 4 & 0 & 2 & 0 & 4 & \\
\hline 入れ歯装填率** & 95.9 & 100 & 100 & 84.6 & 76.5 & 96.4 & 81.0 & 100 & 88.2 & 100 & 88.6 & \\
\hline 残存歯数 & 11 & 12 & 13 & 14 & 15 & 16 & 17 & 18 & 19 & 20 & 21 & \\
\hline \multirow[t]{2}{*}{ 入れ歯 } & 5 & 10 & 4 & 6 & 16 & 11 & 5 & 11 & 3 & 19 & 6 & \\
\hline & 0 & 2 & 0 & 1 & 1 & 2 & 0 & 3 & 2 & 6 & 1 & \\
\hline 入れ歯装填率** & 100 & 83.3 & 100 & 85.7 & 94.1 & 84.6 & 100 & 78.6 & 60.0 & 76.0 & 85.7 & \\
\hline 残存歯数 & 22 & 23 & 24 & 25 & 26 & 27 & 28 & 29 & 30 & 31 & 32 & 合計 \\
\hline \multirow[t]{2}{*}{ 入れ歯 } & 8 & 4 & 9 & 4 & 4 & 2 & 5 & 1 & 2 & 0 & 0 & 410 \\
\hline & 4 & 1 & 3 & 4 & 3 & 8 & 11 & 5 & 2 & 2 & 4 & 87 \\
\hline 入れ歯装填率** & 66.7 & 80.0 & 75.0 & 50.0 & 57.1 & 20.0 & 31.3 & 16.7 & 50.0 & 0 & 0 & 82.5 \\
\hline
\end{tabular}

*残存歯数 0 ～32本の者がそれぞれ何人いて,そのうちの何人が入れ歯を装填しているのかを調べたもの **入れ歯有 $/($ 入れ歯有 + 入れ歯無 $) \times 100$ 
表 8 噛み具合と入れ歯の有無の関係

\begin{tabular}{|c|c|c|c|c|c|}
\hline \multirow[b]{2}{*}{ 入れ歯 } & \multicolumn{4}{|c|}{ 噛及具合 } & \multirow[b]{2}{*}{ 合計 } \\
\hline & 良い & 普通 & あまり良くない & 良くない & \\
\hline 有 & $90(16.8)$ & $333(62.1)$ & $83(15.5)$ & $30(5.6)$ & $536(100)$ \\
\hline 無 & $40(30.5)$ & $70(53.4)$ & $10(7.6)$ & $11(8.3)$ & $131(100)$ \\
\hline
\end{tabular}

回答した者は 667 人，（）内は\%

\section{4 ) 飲み込み具合}

飲み込及具合については，回答者の $92.2 \%$ 「良い」(32.0\%) もしくは 「普通」(60.2\%) として打り，「あま り良くない」(6.4\%) と「良くない」 (1.4\%) を大きく上回っていた（表10）。 な抢，年代の上昇に伴い「良くない」 と「あまり良くない」の割合が増加し

\section{表 9 噛み具合に関する愁訴の内容別件数}

\begin{tabular}{lc}
\hline \multicolumn{1}{c}{ 愁訴の内容 } & 件数 \\
\hline 歯, 歯ぐきの異状による咀嚼障害 & $80(72.0)$ \\
咀嚼障害 & $24(21.6)$ \\
口腔内機能異常 & $2(1.8)$ \\
口腔内神経異常 & $2(1.8)$ \\
遅食い & $2(1.8)$ \\
詰まり & $1(0.9)$ \\
\hline \multicolumn{1}{c}{ 合 計 } & $111(100)$ \\
\hline & $($ ) $)$ 内は\%
\end{tabular}

の者で $12.1 \% ， 6.0 \%$ とそれらの中間であった。また， 療養中の者では，時々悪くなる者と同程度であった。一 方，噛み具合に「問題がない」（すなわち「良い」と 「普通」の合計）は，健康状態の良い者で $91.8 \%$ ，普通 の者で $81.9 \%$, 時々悪くなる者で 62.7 \%と順次減少していた。なお，療養中 の者では「時々悪くなる」の場合と同 程度であった。以上より，噛み具合は 健康状態と対応していることがわかっ た。

噛み具合の程度を入れ歯の有無との 間で比べてみたところ，「有」では 「良い」「普通」の合計が78.9\%，「無」 では $83.9 \%$ であった（表 8 )。入れ歯 を装填すれば噛及具合が改善するので 「有」の割合が「無」よりも高まるは ずであるが，そうなってはいなかった。 その原因は装填の不具合にあると思わ れる。実際，噛久具合に関する愁訴内 容には，「入れ歯があわない」「入れ歯 のためよく噛めない」などが多かった。

噛み具合に関する具体的な愁訴は 111件寄せられており，前段の内容以 外にも「歯がない」「歯茎で噛んでい る」など，歯や歯茎の異常による咀嚼 障害の訴えが80件（全件数の $72.0 \%$ ） と多数寄せられていた（表 9 )。した がって，入れ歯を矯正するなど歯を適 切に治療することで咀嚼状態の改善が 図られると見达まれた。
て抢り（表10），同様の傾向は健康状態が芳しくない場 合にもみられた（表11）。

飲み込久具合を入れ歯の有無との間で比べてみると， 「無」では「良い」「普通」の合計が90.3\%であるのに対 して，「有」では $92.7 \%$ とや高くなっていた（表12）。 よって，入れ歯の装填が飲久込久具合に及ぼす効果は, あまり高くはないものと見受けられた。

飲み込み具合の愁訴については47件の記入があり，そ の内容の多くは「むせる」「つかえる」など嚥下障害に 関わるものであった（表13）。

\section{5 ）噛み具合と飲み込み具合の比較}

ぞの年代，どの段階の健康状態を比べてみても，「噛 み具合」の思わしくない者は「飲み込み」に不具合を来 たしている者よりも多い状態にあった（表 $6 ， 7 ， 10$, 11)。ちなみに，「噛久具合」が「あまり良くない」また

表10 飲み込み具合の状態（年代別人数）

\begin{tabular}{|c|c|c|c|c|c|}
\hline \multirow[b]{2}{*}{ 年齢構成 } & \multicolumn{4}{|c|}{ 飲み込み具合 } & \multirow[b]{2}{*}{ 合計 } \\
\hline & 良い & 普通 & あまり良くない & 良くない & \\
\hline $65 \sim 69$ 歳 & $70(41.7)$ & $92(54.8)$ & $4(2.4)$ & $2(1.2)$ & $168(100)$ \\
\hline 70歳代 & $107(30.1)$ & $226(63.5)$ & $19(5.3)$ & $4(1.1)$ & $356(100)$ \\
\hline 80歳代 & $47(28.0)$ & $99(58.9)$ & $20(11.9)$ & $2(1.1)$ & $168(100)$ \\
\hline 90歳以上 & $12(26.7)$ & $27(60.0)$ & $4(8.9)$ & $2(4.4)$ & $45(100)$ \\
\hline 合計 & $236(32.0)$ & $444(60.2)$ & $47(6.4)$ & $10(1.4)$ & $737(100)$ \\
\hline
\end{tabular}

表11 飲み込み具合と健康状態の関係

\begin{tabular}{|c|c|c|c|c|c|}
\hline \multirow[b]{2}{*}{ 健康状態 } & \multicolumn{4}{|c|}{ 飲み込み具合 } & \multirow[b]{2}{*}{ 合計 } \\
\hline & 良い & 普通 & あまり良くない & 良くない & \\
\hline 良い & $109(58.0)$ & $76(40.4)$ & $3(1.6)$ & $0(0)$ & $188(100)$ \\
\hline 普通 & $86(23.5)$ & $262(71.6)$ & $15(4.1)$ & $3(0.8)$ & $366(100)$ \\
\hline 時々悪くなる & $10(16.4)$ & $42(68.9)$ & $7(11.5)$ & $2(3.2)$ & $61(100)$ \\
\hline 療養中 & $19(21.3)$ & $48(53.9)$ & $19(21.3)$ & $3(3.3)$ & $89(100)$ \\
\hline
\end{tabular}

回答した者は704人，（）内は\%

表12 飲み込み具合と入れ歯の有無の関係

\begin{tabular}{c|cccc|c}
\hline \multirow{2}{*}{ 入れ歯 } & 良い & \multicolumn{4}{|c|}{$\begin{array}{c}\text { 飲み込み具合 } \\
\text { 普通 }\end{array}$} \\
\hline あまり良くない & 良くない & 合計 \\
\hline 無 & $174(30.7)$ & $351(62.0)$ & $36(6.4)$ & $5(0.9)$ & $566(100)$ \\
\hline
\end{tabular}

回答した者は 700 人，（）内は\% 
表13 飲み込み具合に関する愁訴の内容別件数

\begin{tabular}{|c|c|}
\hline 愁訴の内容 & 件数 \\
\hline 曣下障害 (むせる, つかえるなど) & $36(76.6)$ \\
\hline 咀嚼·嚥下障害 & $10(21.3)$ \\
\hline 口腔内炎症 & $1(2.1)$ \\
\hline 合 計 & $47(100)$ \\
\hline
\end{tabular}

（）内は\%

は「良くない」とする者が全体平均で19.6\%（表 6 ）で あるのに対して，「飲み込久具合」については7.8\%（表 10)であった。

噛み具合は，入れ歯を正しく装填するなどの処置によ り比較的容易に改善できる。噛み具合が良くなれば咀嚼 が進むので, 飲久込久の「不具合」もある程度は解消で きるはずである。しかしながら，飲み込みの「不具合」 に関する愁訴内容は，「咀嚼」の不十分さに直接関わる ものが少なく, 咀嚼後に問題になるようなものが多くを 占めていた（表13）。したがって，入れ歯を装填して噛 み具合を良くしても，飲み达みの不具合が劇的に改善さ れはしないことが示唆された。

健康状態との関係では，「噛久具合」の不具合が健康 度の低下とともに顕著に高まってはいるものの，「時々 悪くなる」と「療養中」との間で健康度に差が認められ なくなっていた（表 7 ）。その一方で，「飲久込み」の不 具合は，健康度の低下に応じて上昇し続けていた（表 11)。

これらから，「噛み具合」以上に「飲み込み具合」が, 健康状態や年代（年齢）と明確な対応関係にあることが わかった。

高齢になると，健康状態が良好であっても身体の各所 で機能低下が抢きていることが多い。それらの機能低下 が「飲み込み」の不具合さに繋がっている可能性があり， さらなる検討が待たれる。

\section{(4) 食事内容}

1）主食, 主菜, 副菜, 漬物, 汁物について

食事内容を主食, 主菜, 副菜, 漬物, 汁物に区分し, 朝食, 昼食, 夕食ごとにそれらの摂取状況を調べた（表 14）。主食は 3 食ともほとんどの対象者 (95.4\%) が摂 って抢り，とりわけ朝食での摂取が高い状態 (96.8\%) にあった。主菜については, 朝食 $(83.1 \%)$ や夕食 (81.7\%) で摂取する頻度が高く，昼食では50\%に満た なかった。副菜は夕食での摂取頻度が高く（83.1\%）, 次いで昼食, 朝食の順であった。漬物の摂取は平均して $50 \%$ 以下であるが，朝食での摂取が59.6\% と高い状態に あった。汁物は朝食で摂取する者が多く $(89.1 \%)$, 次 いで夕食となっており，昼食での摂取は低い状態（39.5 \%)にあった。

以上より, 対象者の朝食は「主食·主菜·汁物」型で
表14 主食, 主菜, 副菜, 漬物, 汁物の摂取人数

\begin{tabular}{|c|c|c|c|c|}
\hline \multirow[b]{2}{*}{ 食事内容 } & \multicolumn{3}{|c|}{ 食事の種類 } & \multirow[b]{2}{*}{ 延べ人数 } \\
\hline & 朝食 & 昼食 & 夕食 & \\
\hline 主 食 & $735(96.8)$ & $720(94.9)$ & $718(94.6)$ & $2173(95.4)$ \\
\hline 主 菜 & $631(83.1)$ & $360(47.4)$ & $620(81.7)$ & $1611(70.8)$ \\
\hline 副 菜 & $447(58.9)$ & $460(60.6)$ & $631(83.1)$ & $1538(67.5)$ \\
\hline 漬 物 & $452(59.6)$ & $301(39.7)$ & $299(39.4)$ & $1052(46.2)$ \\
\hline 汁 物 & $676(89.1)$ & $300(39.5)$ & $527(69.4)$ & $1503(66.0)$ \\
\hline
\end{tabular}

回答した者は 759 人，（）内は\%

あるといえる。朝食では「副菜」の摂取が少ないので関 連食材の不足が懸念されるかに見受けられるが，具を多 くした汁物を用意すればそのような心配は払拭できる。

一方，「主食」型の昼食では，「一血メニュー」(チャー ハン, カレーライス, 麺類など）を食する者が $27.8 \%$ と 多かった。一血メニューは, 咀嚼・䱔下障害の人でも食 しやすい雑炊のようなものから，焼きそばやグラタンな ど若者向きのメニューに至るまでバラエティーに富んで いた。一皿メニューの場合は，たんぱく質，ビタミン・ ミネラル類，食物繊維などがどうしても不足がちになる。 ゆえに，意識して $1 ， 2$ 皿を補うような配慮が必要であ る。

朝食時の主食, 主菜, 副菜, 漬物, 汁物の摂取頻度と 健康状態の間に対応関係が見られるかどうかを検討した。 「漬け物」は, 年代の高まり, 健康状態の低下, 噛久具 合の悪化, 飲み込久状態の低下に伴い摂取頻度が低下す る傾向にあった。とりわけ噛み具合と飲み込久状態の悪 化で大きく低下していた（図 $1 \mathrm{a} \sim \mathrm{d}$ )。なお，漬け物 以外は対応関係が見られなかった。

\section{2 ）主食の内容}

主食の材料は米（米飯，粥など）が最も多く 3 食平均 で $82.2 \%$ であり，小麦粉製品（麺，パンなど）の $17.7 \%$ を大きく上回っていた。とくに朝食ではほとんどの者 (93.9\%) が米を食していた。ただし昼食では小麦製品 を摂る者が $34.8 \%$ と高くなっていた（表15）。

主食をどのような料理で摂取しているのかを朝食で調 べた。米の場合, 米飯が極めて多く $(96.1 \%)$ 粥はわず か (3.8\%) であり, 小麦粉製品ではほとんどがパンで あった $(97.7 \%)$ (表16)。

\section{3 ) 主菜の材料や汁物の具について}

主菜として摂取頻度の最も高かった材料は魚(43.1\%) であり，次いで大豆製品 $(23.9 \%)$, 卵 $(23.9 \%)$, 肉 (14.9\%) の順であった。なお，朝食では大豆料理，魚， 卵を, 昼食では魚と卵を, 夕食では魚と肉を高頻度に食 していた（表17）。

汁物の具については, 最も多く利用しているものは大 根·白菜・キャベッなどのいわゆる「その他の野菜」 (32.9\%) であり，次いで豆腐・油揚げ・うち豆などの 「大豆製品」(19.0\%) や「イモ類」(16.4\%) であった。 肉・卵・貝類などの動物性食品の利用は全体で $5 \%$ に満 

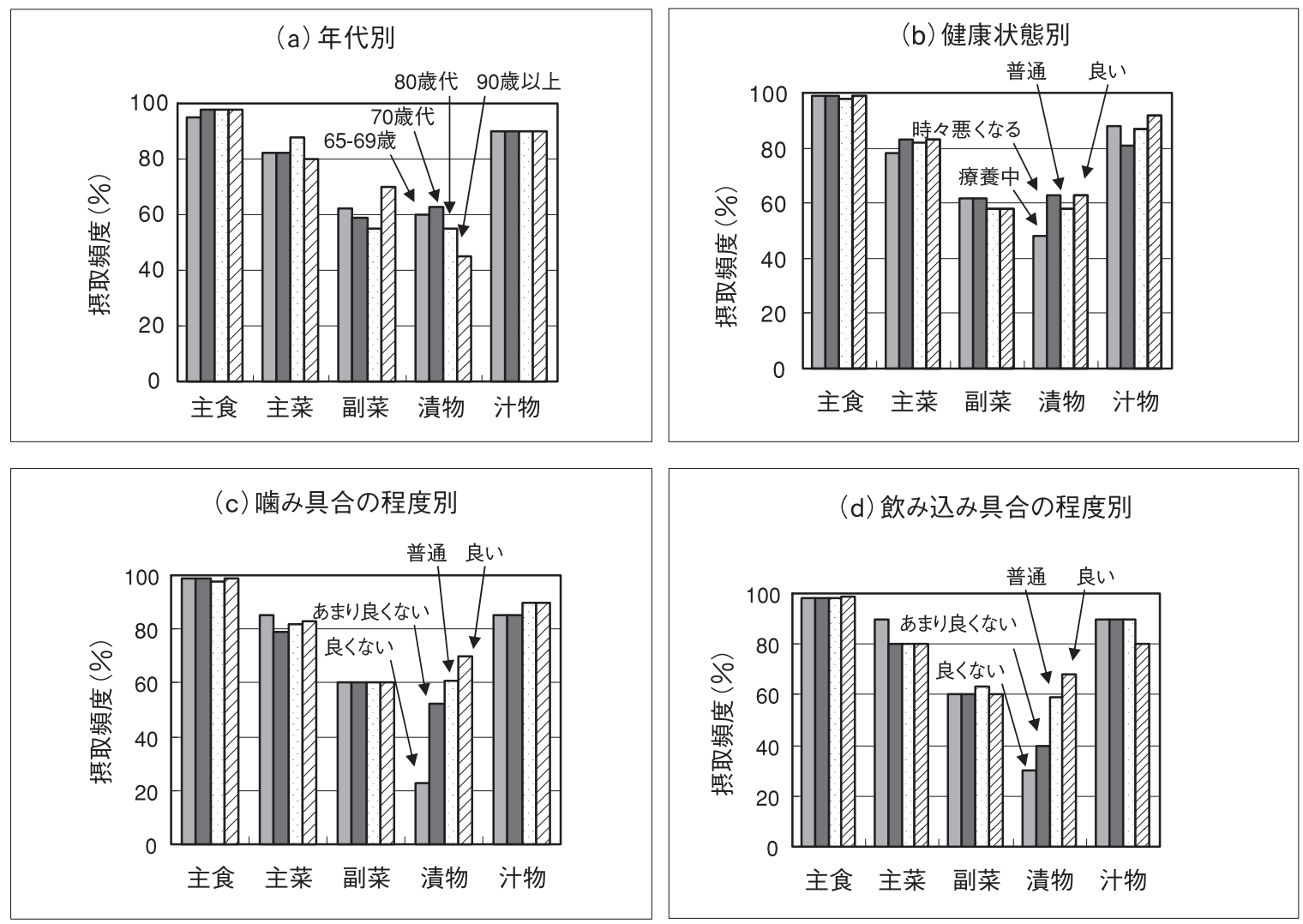

図 1 朝食時の主食, 主菜, 副菜, 漬物, 汁物の摂取情況

\begin{tabular}{|c|c|c|c|c|}
\hline \multirow[b]{2}{*}{ 内 容 } & \multicolumn{3}{|c|}{ 食事の種類 } & \multirow[b]{2}{*}{ 合 計 } \\
\hline & 朝食 & 昼食 & 夕食 & \\
\hline $\begin{array}{l}\text { 米（米飯，粥など） } \\
\text { 小麦粉製品（麺，パンなど） } \\
\text { 液状食品（エンシュアリキッド，牛乳など） }\end{array}$ & $\begin{array}{r}691(93.9) \\
43(5.8) \\
2(0.3)\end{array}$ & $\begin{array}{r}483(65.2) \\
258(34.8) \\
0(0)\end{array}$ & $\begin{array}{r}641(87.6) \\
91(12.4) \\
0(0)\end{array}$ & $\begin{array}{r}1815(82.2) \\
2(0.1)\end{array}$ \\
\hline 計 & $736(100)$ & $741(100)$ & $732(100)$ & $2209(100)$ \\
\hline
\end{tabular}

回答した者は朝食 737 人, 昼食 743 人, 夕食 733 人

そのうち食事を摂らなかった者は朝食 1 人, 昼食 2 人，夕食 1 人，（）内は\%

表16 朝食時の主食の料理と摂取人数

\begin{tabular}{|c|c|c|}
\hline 材 料 & 料理名 & 摂取人数 \\
\hline \multirow[t]{3}{*}{ 米 } & 米 飯 & $664(96.1)$ \\
\hline & 粥 & $26(3.8)$ \\
\hline & も ち & $1(0.1)$ \\
\hline \multirow[t]{2}{*}{ 小麦粉製品 } & パン & $42(97.7)$ \\
\hline & どん & $1(2.3)$ \\
\hline 液 体 & エンシュアリキッド・牛乳など & $2(100)$ \\
\hline
\end{tabular}

表17 主菜の内容

\begin{tabular}{c|r:r:r:r}
\hline 主菜の材料 & \multicolumn{1}{|c}{ 朝食 } & \multicolumn{1}{c}{ 昼食 } & 夕食 & 合計 \\
\hline 魚 & $312(31.9)$ & $218(48.3)$ & $477(52.4)$ & $1007(43.0)$ \\
肉 & $63(6.4)$ & $68(15.1)$ & $218(24.0)$ & $349(14.9)$ \\
卵 & $259(26.5)$ & $101(22.4)$ & $65(7.1)$ & $425(18.2)$ \\
大豆料理 & $344(35.2)$ & $64(14.2)$ & $150(16.5)$ & $558(23.9)$ \\
\hline 合 計 & $978(100)$ & $451(100)$ & $910(100)$ & $2339(100)$ \\
\hline \multicolumn{5}{c}{ ( )内は\% }
\end{tabular}


表18 汁物の具の内容（複数回答）

\begin{tabular}{|c|c|c|c|c|}
\hline 汁物の具材 & 朝食 & 昼食 & 夕食 & 合 計 \\
\hline その他の野菜（大根·白菜·キャベッなど） & $519(32.5)$ & $188(33.7)$ & $447(33.1)$ & $1154(32.9)$ \\
\hline 大豆製品 & $322(20.2)$ & $110(19.7)$ & $235(17.4)$ & $667(19.0)$ \\
\hline イモ類 & $301(18.8)$ & $77(13.8)$ & $197(14.6)$ & $575(16.4)$ \\
\hline 海藻類 & $187(11.7)$ & $72(12.9)$ & $104(7.7)$ & $363(10.4)$ \\
\hline 緑黄色野菜 & $154(9.6)$ & $52(9.3)$ & $147(10.9)$ & $353(10.1)$ \\
\hline きのこ類 & $61(3.8)$ & $23(4.1)$ & $80(5.9)$ & $164(4.7)$ \\
\hline 動物性食品 & $39(2.4)$ & $30(5.3)$ & $98(7.3)$ & $167(4.8)$ \\
\hline コンニャク & $8(0.5)$ & $2(0.4)$ & $34(2.5)$ & $44(1.3)$ \\
\hline 麥处 & $7(0.4)$ & $4(0.7)$ & $7(0.5)$ & $18(0.5)$ \\
\hline 合計 & 1598(100) & $558(100)$ & $1349(100)$ & $3505(100)$ \\
\hline
\end{tabular}

表19 汁に入れた具の数

\begin{tabular}{|c|c|c|c|c|c|c|c|c|c|c|c|}
\hline \multirow[b]{2}{*}{ 食事の種類 } & \multicolumn{10}{|c|}{ 具の数 } & \multirow[b]{2}{*}{ 平 均 } \\
\hline & 0 & 1 & 2 & 3 & 4 & 5 & 6 & 7 & 8 & 9 & \\
\hline 朝 食 & 40 & 81 & 278 & 196 & 47 & 17 & 10 & 2 & 4 & 1 & 2.4 \\
\hline 昼 食 & 50 & 59 & 114 & 50 & 15 & 6 & 4 & 2 & - & - & 1.9 \\
\hline 夕 食 & 46 & 60 & 202 & 112 & 45 & 19 & 19 & 18 & 3 & 3 & 2.6 \\
\hline
\end{tabular}

たなかった（表18）。汁物に入れる具の数は平均して 2 〜 種類であった（表19）。

\section{4 ）その他の食品の摂取状況}

主食, 主菜, 副菜, 漬物以外の食品を「その他の食品」 とし，それらの食品の種類と摂取状況を表 20 ととめた。 果実類がよく食されて抽, とくに朝食と夕食での摂取 が多かった。リンゴ，ミカン， カキ，バナナ，キウイ， イチゴ，パパイヤなどの生の果実のほか，乾燥果物（干 し柿）や缶詰など多種類の記載があった。表には示して いないが，和菓子や洋菓子など菓子類の記入も数多くあ りデザートを楽しんでいる様子が伺われた。

\section{5 ）食事の工夫など}

「工夫していること」や「あればよいと思う食品」な どの記載を求めたところ, 前者に関しては「薄味にする」 (44人) と「軟らかくする」(23人) が多く，「刻む」（6 人),「とろみをつける」（2 人）などもあった（表 $21 ） 。$

表20 その他の食品（主食, 主菜, 副菜, 漬物, 汁物以外) の摂取人数

\begin{tabular}{|c|c|c|c|c|}
\hline 食品の種類 & 朝食 & 昼食 & 夕食 & 合 計 \\
\hline 牛 乳 & $89(23.3)$ & $96(25.1)$ & $197(51.6)$ & $382(100)$ \\
\hline ヨーグルト & $88(40.0)$ & $70(31.8)$ & $62(28.2)$ & $220(100)$ \\
\hline ジュース & $41(16.6)$ & $16(60.5)$ & $190(76.9)$ & $247(100)$ \\
\hline 打 茶 & $70(26.1)$ & $158(59.0)$ & $40(14.9)$ & 268(100) \\
\hline 果実類 & $399(37.4)$ & $281(26.3)$ & $387(36.3)$ & $1067(100)$ \\
\hline 酒 類 & $0\left(\begin{array}{ll}0 & )\end{array}\right.$ & $0\left(\begin{array}{ll}0 & )\end{array}\right.$ & $152(100)$ & $152(100)$ \\
\hline
\end{tabular}

$124(30)$
表21食事の工夫（自由記載）

\begin{tabular}{lcc}
\hline \multicolumn{1}{c}{ 記載内容 } & 人数 & 備 考 \\
\hline 薄味にする & 44 & \\
軟らかくする & 23 & \\
介護食を希望する & 18 & うち 3 人は使用中 \\
刻む & 6 & \\
食材の宅配を利用 & 6 & \\
飲み込みやすいようにとろみをつける & 2 & \\
\hline
\end{tabular}

普通の食材を食しやすくするための「調理時のさまざま な工夫の跡」がみて取れる。なお，軟らかくしたりトロ ミを付けたりする際には調理過程で水分が多く加えられ ることから，いわゆる「薄い」食事になり高齢者の低栄 養状態を助長しかねなくなることに留意すべきである。

後者に関しては，介護食を望む声が高く（18人），そ

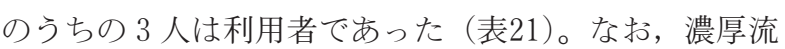
動食の利用者も 1 人いた。ところで, 噛久具合の思わし くない者（「あまり良くない」「良くない」を合わせて $19.6 \%$, 表 6 ) や飲及达久具合の芳しくない者（「あま り良くない」「良くない」を合わせて7.8\%, 表10）が多 い状態であるにもかかわらず，市販の高齢者用食品を利 用している者はわずか 4 人であった。したがって, 関連 食品がそれほど市民に浸透してはいない状況にある。 「高齢者はあまり食べなくても構わない」「高齢になると 食事量が減るのは当然」などといった意識が当事者や家 族に浸透している限り，食事の内容や量はさし て気にならず，市販の高齢者用食品や濃厚流動 食などに関心が向くこともない。市販されてい る高齢者用食品や濃厚流動食の利用者が少ない 原因の一つが，こうした意識の者が多いことに あると思われる。その一方で, 介護食を,「あ れば良い（便利な）食品」に位置づける者が少 なからずおり，咀嚼・嚥下状態に併せた「食事 づくり」の大変さを伺うことができる。

以上より, 高齢者向け食品や高齢者向け献立 の必要性や要望が高いものと判断できた。 


\section{今後の改善点}

これまでの調査結果と考察に基づき, 高齢者の食生活 環境の改善点を以下のようにまとめた。

（1）高齢者が快適に食事をすることのできる環境づく りが大切である。

自歯が 1 本も無い者が 5 人に 1 人もいるなど残存歯の 少ない高齢者が多く, 結果として入れ歯の装填者が多い 状態にあった。しかしながら，装填具合の良くないケー スが多々見受けられた。歯抜け状態を「我慢」している 高齢者も少なからずいた。よって高齢者には，口腔内衛 生を保つことの大切さや快適さを認識し, 積極的に歯科 治療を受けるようになってもらう必要がある。そのため には，高齢者の健康づくりを多方面からサポートできる 専門家を配置したり，高齢者の歯科保健対策を充実させ たりしなければならない。

（2）高齢者が摂取する食べ物については，多方面から の改善・改良が必要である。

たとえばメニューの点では，昼食を単品で斉ます高齢 者が多く栄養補給に偏りを来たしかねない状態にあるの で，高齢者用に工夫・改善された昼食メ二ューの提供が 望まれる。最近の急速な高齢化の進行，高齢単身世帯や 高齢夫婦世帯の著しい増加などから，高齢者が食事を準 備しやすいように便宜をはかる必要もある。具体策の一 つが，高齢者やその家族が利用できやすくするために高 齢者向け食材の宅配サービスや配食サービスを普及させ ることであろう。

（3）咀嚼・嬿下障害に対応した高齢者用食品の開発と

普及をはかることが望をれる。

高齢者が食べ慣れた食材を，各人の咀嚼・嬿下状態の 程度に応じて調製できることを念頭に置いた高齢者用食 品の開発が期待される。同時に，咀嚼・嚥下に問題のあ る高齢者がそれらの食品を入手しやすくするための体制 を整える必要がある。

\section{N. 要 約}

在宅高齢者の健康状態，歯（咀嚼）と喉（嚥下）の具 合ならびに食生活の現状を把握するための調査を行い， 以下のような結果を得た。

(1) 健康状態

健康状態は，80歳代までは年代の上昇に伴い低下する 傾向にあったが90歳以上では逆転していた。

（2）歯（咀嚼）と喉（嚥下）の具合

自歯の無い者が $20 \%$ 以上いた。残存歯数は平均 11 本 （残存率33.8\%）であり，年代（年齢）の上昇に伴い減 少していた。

入れ歯の装填率は $80 \%$ を上回っていた。残存歯が 19 本 (残存率 $59.4 \%$ ) 程度以下になると装填率が特に高くな
り，それを上回った場合は装填率が大きく低下していた。 ただし，入れ歯の装填状態に不具合を感じている者が多 数見受けられた。

「噛み具合」に不都合を来している者（19.6\%）は 「飲み込久具合」に不具合を感じている者（7.8\%）より も多かった。なお，「噛み具合」の程度以上に，「飲久込 久具合」の程度が，健康状態と強く対応していた。

(3) 食事内容

米飯を主食として摂取している者が圧倒的に多く，と くに朝食で顕著であった。一日の食事では, 朝食が栄養 や食品のバランスが取れていると見受けられた。昼食で は一皿メニューの利用が多いので，栄養補給の点で問題 である。デザートとして果物類がよく食されていた。

漬物の摂取頻度は，年代（年齢）の上昇，健康状態の 悪化, 噛久具合や飲み达み具合の低下などに伴い減少し ていた。それ以外の食物ではとくに対応関係は見られな かった。

市販の高齢者用食品を利用している者は多くなかった。 その一方で，「あれば良い（便利な）食品」として高齢 者用食品を掲げる者も少なからずいた。

上述した(1)〜(3)の解析結果に基づいて，今後の改善点 を指摘した。

\section{謝 辞}

本調査を実施・解析するに当たっては浦上食品・食文 化振興財団ならびに福島県から援助をいただいた。また， アンケート用紙の配布と回収では次の機関にご協力を願 った。原町市役所 (現南相馬市役所) 高齢福祉課, JA 相馬，相馬市社会福祉協議会，JAいわき市営農企画課， JA 新ふくしま生活福祉課, 郡山市長寿社会振興センター, 白河市健康増進課, JA あいづ女性部, 喜多方市保健セ ンター, 田島町（現南会津町）健康増進係。記して感謝 いたします。

\section{文献}

1）内閣府編：平成18年版高齢社会白書，ぎょうせい，東京 (2006)

2）総務省統計局：統計からみた我が国の高齢者一敬老の日 にちなんでー (2002) (http://www.stat.go.jp/data/topics/in fo175.htm)

3）細谷憲政監修：栄養緑書一これでいいのか日本の栄養問 題，日本医療企画（2003）

4）高齢社会対策基本法（平成 7 年法律第129号）（1995）

5）福島県企画調整部情報統計領域生活統計グループ: 福島 県の高齢者人口・世帯（2005）（http://www.pref.fukushima. jp/toukei/data/02kakusyu/kakusyu/keirou/17keirou.pdf)

6）安藤雄一, 青山 旬, 花田信弘 : 口腔が健康状態に及ぼす 影響々歯科保健医療, J.Natl.Inst.Public Health，52（1），23 (2003) 